\title{
An investigation of the incidence of intersex fish in Seine-Maritime and Sussex regions
}

\author{
C. Minier ${ }^{1 *}$, G. Caltot ${ }^{1}$, F. Leboulanger ${ }^{1}$ and E.M. Hill ${ }^{2}$ \\ ${ }^{1}$ LEMA, UPRES-EA 3222, Université du Havre, 25 rue Philippe Lebon, BP 540, 76058 Le Havre Cedex, France \\ ${ }^{2}$ CPES, University of Sussex, England
}

The incidence of intersex was examined in freshwater fish in one English and three French rivers. Over 331 fish, mainly roach, were sampled above and below the major sewage treatment works (STW) on each river and the incidence of intersex was recorded by histological examination of fish gonads. No intersex conditions were observed in male fish collected either above or below the major STW on the River Ouse in Sussex. In contrast, roach showing primary oocytes in their testes were found in all three French rivers with the incidence ranging from 9 to $21 \%$ of the males. An intersex chubb and gudgeon were also caught, showing that other species can suffer from this pathology. In addition, roach in the River Seine were heavily parasitised with the tapeworm Ligula intestinalis which may impair the reproductive capabilities of the fish.

\section{Introduction}

In the past decade, there have been a growing number of reports describing alterations of the endocrine system in numerous species. A number of environmentally persistent chemicals have been shown to be able to mimic endogenous hormones and it has been suggested that they can disrupt the reproductive and endocrine system of humans and wildlife $[1,2]$. In this respect, fish living in polluted environments appear particularly at risk and numerous reports have shown evidence of xenobiotic-induced reproductive disruption (reviewed in $[3,4])$. Among these disturbances, histological examination of fish gonads revealed the occurrence of both male and female tissues within the same organ, thus characterising intersex individuals [5]. Evidence of feminisation of male fish have been reported in wild populations of European flounder, Platichthys flesus, in 2 English estuaries [6] or even at sea, in the English Channel [7]. Similar 
observations were reported in roach, Rutilus rutilus from the Baltic sea [8] and in UK rivers [9]. In the latter study, a high incidence of feminised male roach was recorded. No control site without any feminised fish were found and, in some sites, $100 \%$ of the males were intersex.

A unique feature of the incidence of feminisation in UK rivers and estuaries is that it is particularly high downstream of sewage treatment works (STWs). These types of effluents contain estrogenic substances that induce vitellogenin, the egg yolk protein, synthesis in male flounder [10] or in trout [11]. Other reports have shown that this potency of STW effluents is present in other countries [12,13], although not everywhere [14]. This association between the degree of intersexuality and the plasma vitellogenin concentration in the British rivers suggests that both effects have a common cause and, therefore, that chemicals present in sewage effluents are responsible for the intersexuality in wild fish populations [9]. Although the exact nature of the compound or mixtures of compounds causing these effects has not yet been identified, some rivers and STW effluents contain steroids such as $17 \beta$-oestradiol, oestrone and ethinyloestradiol at concentrations that could cause intersex $[15,16]$. Nevertheless, other estrogenic chemicals have been identified in STW effluents and may contribute to the effects. A number of them correspond to p-alkylphenolic compounds which are derived from the degradation of alkylphenol polyethoxylate surfactants during the sewage treatment process [17].

At present there is little information on the levels of intersex fish in French rivers. Therefore, the aim of this study was to determine whether fish in selected rivers of the East Sussex and Seine-Maritime regions had been exposed to endocrine disrupting pollutants that were likely to impair the fecundity of the resident fish population. Rivers were selected that could contain reasonable populations of cyprinids, particularly roach (Rutilus rutilus) which is a detritus and benthos feeder. In October 1998, sites were sampled upstream and downstream of major STW effluents along each river and fish were analysed for gonad abnormalities. The preliminary results of this first survey in the regions are presented in this report.

\section{Methods}

\section{Sampling sites}

Fish were sampled randomly by electrofishing above and below major sewage effluents on the Rivers Ouse (East Sussex, England), Bresle, Bethune and Seine (SeineMaritime, France) (Fig. 1). The two sampling sites on each of the rivers were separated by weirs which limited the movement of fish upstream. The effluent loading described as adjusted population equivalent (AdjPE) of the influent at the different sites are given in table I. The population equivalent (PE) is calculated as one PE equal to a 5 day
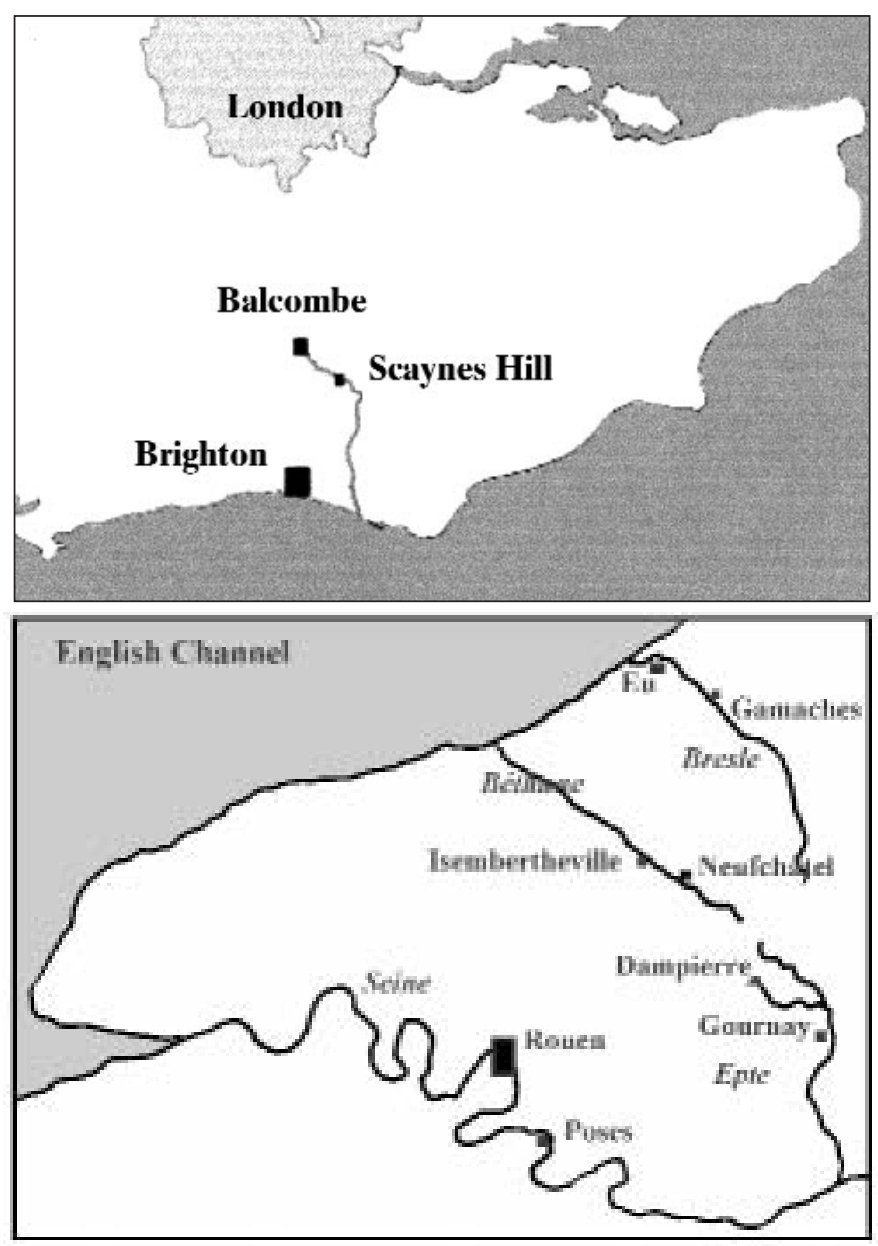

Figure 1. Location of sampling sites.

biochemical oxygen demand (DBO5) of $57 \mathrm{~g}$ of oxygen per day (French sites) or $60 \mathrm{~g}$ of oxygen per day (River Ouse). The PE was adjusted to take into account the dilution of the effluent in the river using mean month river flow data. For the French rivers, data kindly provided by the Agence de l'Eau Seine-Normandie and the Direction Régionale de l'Environnement de Haute-Normandie are partially published [18].

\section{Fish sampling}

Reasonable numbers of roach were caught at most sites and some chubb and gudgeon were also sampled in some rivers. Only sexually mature fish, over $10 \mathrm{~cm}$ length, were sampled. Fish were terminally anaesthetized, the length, and weight were measured. Gonads were dissected out, weighed and preserved in Bouins medium (Sigma, St Louis) for analysis by histology. The gonadosomatic index, a measure of reproductive health of the fish, was calculated as: gonadal weight / (total body weight - gonadal weight $) \times 100$.

\section{Histology}

Gonads from each fish were divided into three equal portions and fixed into Bouins solution for 12 hours. Tissues 
Table I. Characteristics of the sampling sites and of the influents of nearest sewage treatment works. * 1 Population equivalent is measured as a 5-day biochemical demand (DBO5) of $57 \mathrm{~g}$ oxygen per day (French sites) and $60 \mathrm{~g}$ oxygen per day (river Ouse). NA = not applicable.

\begin{tabular}{|c|c|c|c|c|c|}
\hline River & Site & $\begin{array}{l}\text { Influent load } \\
(P E)^{*}\end{array}$ & $\begin{array}{l}\text { STW Flow } \\
\left(m^{3} / \text { day }\right)\end{array}$ & $\begin{array}{l}\text { Dilution } \\
\text { factor }\end{array}$ & Adjusted PE \\
\hline \multirow[t]{2}{*}{ Ouse } & Balcombe & NA & NA & NA & NA \\
\hline & Scaynes Hill & 34,000 & 7,763 & 17 & 2,000 \\
\hline \multirow[t]{2}{*}{ Bethune } & Neufchâtel-en-Bray & 675 & 175 & 789 & 1 \\
\hline & Isambertheville & 2,310 & 3,000 & 75 & 31 \\
\hline \multirow[t]{2}{*}{ Bresle } & Gamaches & 2,800 & 475 & 1,073 & 3 \\
\hline & $\mathrm{Eu}$ & 8,000 & 997 & 534 & 13 \\
\hline \multirow[t]{2}{*}{ Seine } & Poses & 80,000 & 50,000 & 707 & 113 \\
\hline & Rouen & 550,000 & 85,000 & 416 & 1,322 \\
\hline
\end{tabular}

were transferred to $70 \%$ alcohol and dehydrated to $100 \%$ alcohol prior to clearing in Histoclear clearing solution (Sigma, St Louis) for 12 hours. Tissues were embedded in molten wax prior to sectioning at 3-5 $\mu \mathrm{m}$ thickness. All sections were stained with Mayers haematoxylin/eosin (Sigma, St Louis), mounted and carefully examined by light microscopy. Intersex was characterised by the presence of primary and secondary oocytes within the testes.

In addition any other indications of gonad abnormalities were noted such as the presence of signs of inflammation or necrosis within the gonads.

\section{Results and discussion}

\section{Incidence of intersex and gonad abnormalities}

The sex ratio and incidence of intersex in roach and chubb are given in tables II and III. No intersex roach were observed at sites upstream or downstream of the major STW of the River Ouse in Sussex. All the 47 male roach caught on the River Ouse showed normal tubular testicular structure and presence of spermatogonias and spermatocytes. Furthermore, none of the 19 male chubb also sampled at Scaynes Hill showed any signs of intersex or abnormal gonad histology. The female cyprinids showed normal gonad histology with lobular structure and presence of oogonia and primary oocytes. The STW at Scaynes Hill is the major effluent input into the River Ouse and this data suggest that there was no deleterious effects of the STW on the reproductive health of the fish population downstream from the works. The data also suggest that the incidence of ovotestis in fish from the River Ouse is negligible compared to that of some other British rivers [9].

Intersex was recorded in the three sampled French rivers. A few primary oocytes (up to 20) were disseminated among male tissue. In roach, this male tissue was generally devoid of spermatocytes, suggesting that normal spermatogenesis was not occurring. On the contrary, in one intersex gudgeon caught at Poses on the River Seine, spermatozoids were present (Fig. 2). Furthermore in that gudgeon, some oocytes showed more than one nucleus suggesting that chemicals have impaired cell division. A similar observation was made with oocytes of rats treated with diethylstilbestrol (DES) [19]. On the River Bethune, one chubb showed the presence of an external oocyte (Fig. 3). The severity of intersex in roach was characterised by the low number of only primary oocytes within the testes and corresponds to the score of 2 on the scale defined by Jobling et al. [9] and is thus much lower than in some English rivers.

On the River Bresle, no intersex fish were caught on the upstream site at Gamaches, however $9 \%$ of the males caught downstream of the major sewage works at Eu had ovotestes. Similarly, on the River Bethune, 1 out of 28 male chubb caught downstream of the STW showed intersex characteristics in the gonads while all of the 11 male from upstream the STW (at Neufchâtel-en-Bray) had normal gonad histology. But surprisingly, 3 out of $14(21 \%)$ male roach caught at Neufchâtel-en-Bray were intersex. Yet, this site is contaminated by only a small STW located $8 \mathrm{~km}$ upstream. Comparison with roach living downstream Neufchâtel-en-Bray was not possible due to the lack of fish there.

Above Rouen, at Poses, 1 out the 3 male roach and 1 out of 3 male gudgeon showed intersex conditions. These results (although none of the 3 male chubb were intersex) could suggest that incidence of ovotestis is high in the Seine. However due to the small numbers of fish caught it was not possible to estimate the incidence of intersex in this population. The poor numbers and diversity of fish in the River Seine can be explained by both the pollution and by the inefficiency of electrofishing in large rivers.

No abnormalities in the sex ratio was detected for roach populations at any of the sites and, where reasonable numbers of roach were sampled, the percentage of males in the 
Table II. Sex ratio and incidence of intersex in roach at each site.

\begin{tabular}{lcccc}
\hline Sites & Number of roach & Number of males & Sex ratio (\% male) & \% intersex \\
\hline Balcombe & 57 & 25 & 44 & 0 \\
Scaynes Hill & 43 & 22 & 51 & 0 \\
Neufchâtel-en-Bray & 26 & 14 & 54 & 21 \\
Isambertheville & - & - & - & - \\
Gamaches & 59 & 33 & 46 & 0 \\
Eu & 47 & 23 & 23 & 9 \\
Poses & 13 & 4 & - & - \\
Total & 245 & 121 & & - \\
\hline
\end{tabular}

Table III. Sex ratio and incidence of intersex in chubb at each site.

\begin{tabular}{lcccc}
\hline Sites & Number of chubb & Number of males & Sex ratio (\% male) & \% intersex \\
\hline Balcombe & - & - & - & - \\
Scaynes Hill & 25 & 19 & 76 & 0 \\
Neufchâtel-en-Bray & 14 & 11 & 73.7 & 0 \\
Isambertheville & 38 & 28 & - & - \\
Gamaches & - & - & - & - \\
Eu & - & 3 & 60 & 0 \\
Poses & 5 & 61 & - & - \\
Total & 82 & & \\
\hline
\end{tabular}

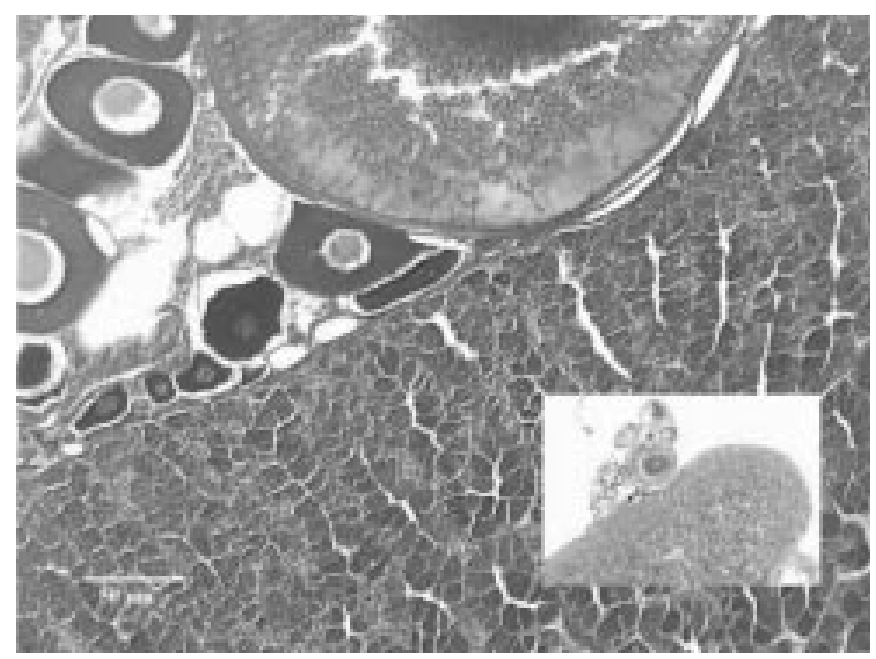

Figure 2. Section of gonad of a male chubb from the River Bethune showing an external primary oocyte.

population varied between 44 and $57 \%$. However, the percentage of male chubb varied from 74 to $78 \%$.

\section{Gonado-somatic index (GSI)}

There were differences between rivers, and between sites on a river, in mean body weight and length of the sampled

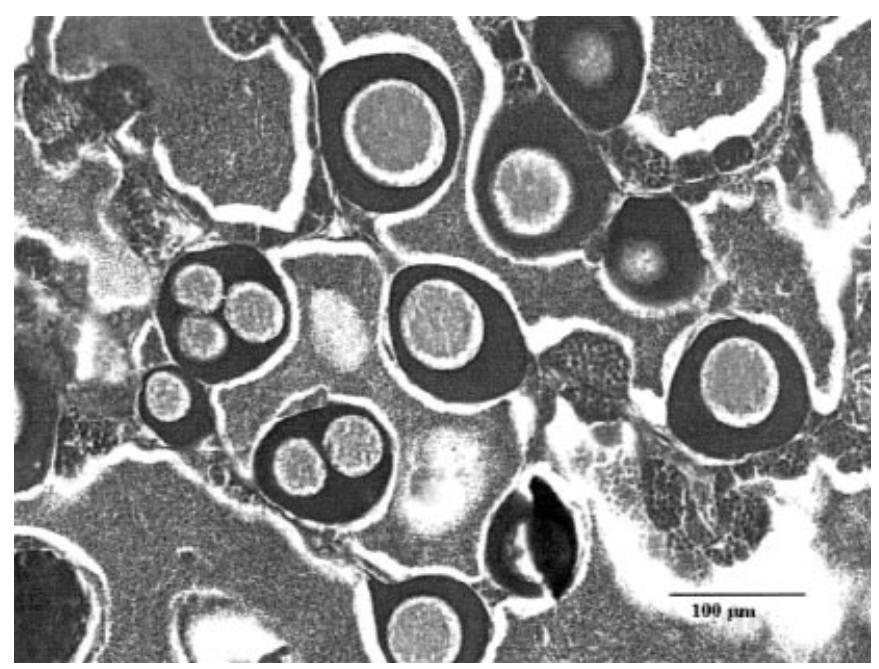

Figure 3. Section of gonad of a male gudgeon from the River Seine showing primary oocytes within male tissue. One oocyte shows three nuclei.

roach (Table IV). These parameters were generally higher in roach caught in Seine-Maritime rivers than those in the River Ouse. On the River Bethune, at Neufchâtel, the body weight and length of roach were significantly higher than at any other site which may reflect an older population sampled there. 
Table IV. Characteristics of the sampled roach. Data expressed as mean \pm s.e. GSI = gonadosomatic index.

\begin{tabular}{|c|c|c|c|c|c|c|}
\hline \multirow[b]{2}{*}{ Sites } & \multicolumn{3}{|c|}{ Males } & \multicolumn{3}{|c|}{ Females } \\
\hline & Body weight $(g)$ & Length $(\mathrm{cm})$ & GSI (\%) & Body weight (g) & Length (cm) & GSI (\%) \\
\hline Balcombe & $19.7 \pm 0.3$ & $11.2 \pm 0.1$ & $1.9 \pm 0.1$ & $23.4 \pm 0.2$ & $12.1 \pm 0.1$ & $4.2 \pm 0.1$ \\
\hline Scaynes Hill & $31.5 \pm 0.9$ & $12.8 \pm 0.1$ & $2.3 \pm 0.1$ & $62.2 \pm 3.6$ & $14.9 \pm 0.2$ & $4.7 \pm 0.1$ \\
\hline Neufchâtel & $152.7 \pm 5.1$ & $20.4 \pm 0.3$ & $3.2 \pm 0.1$ & $276.8 \pm 3.9$ & $24.5 \pm 0.1$ & $9.5 \pm 0.2$ \\
\hline Gamaches & $42.4 \pm 1.7$ & $12.7 \pm 0.1$ & $2.9 \pm 0.1$ & $83.5 \pm 4.7$ & $14.3 \pm 0.2$ & $3.6 \pm 0.1$ \\
\hline $\mathrm{Eu}$ & $50.1 \pm 2.6$ & $13.5 \pm 0.2$ & $3.1 \pm 0.1$ & $94.5 \pm 3.7$ & $16.3 \pm 0.2$ & $4.9 \pm 0.1$ \\
\hline Poses & $80.4 \pm 11.2$ & $17.6 \pm 1.3$ & $1.2 \pm 0.2$ & $24.5 \pm 2.8$ & $12.9 \pm 0.6$ & $1.0 \pm 0.2$ \\
\hline
\end{tabular}

The gonadosomatic index of roach is given in table IV. At sites on the River Bresle and Bethune, where intersex roach were observed, the male GSI was not significantly reduced. However, at Poses on the River Seine, although the body weight and length were comparable to fish caught from some of the other sites, the GSI of both male and female roach was significantly lower. Despite the small sample size, this suggests a factor at Poses which is severely affecting the reproductive health of both male and female roach. In contrast to other sites, a high proportion, $46 \%$ compared to less than $5 \%$, of the male and female roach caught in the Seine were parasitised with Ligula intestinalis. This tapeworm has been shown to interfere with the pituitary-gonadal axis of the fish, by suppressing the secretion of gonadotrophins or gonadotrophin releasing hormones [20]. Gonad development in parasitised fish is therefore poor or non-existent and this may account for the poor GSI of fish caught in the River Seine.

\section{Conclusions}

This study shows that the incidence and severity of ovotestes is low. Data from this preliminary survey indicates that the River Ouse appears to have good water quality and fish show no signs of intersex and a low incidence of parasitism. There appears to be no effect of the major STW on the river on fish reproductive health.

Intersex fish were found in all of the three rivers sampled in France. The incidence of intersex was however rather low with all values never exceeding $25 \%$. Furthermore, the severity of intersex characterised by a low number of only primary oocytes within the testes corresponds to a score of 2 (out of a maximum of 7) on the scale defined by Jobling et al. [9]. Consequently, the intersex condition in the sampled French rivers appeared lower than in some English rivers. However, the STW load as calculated by the adjusted population equivalent of the sampling sites is much lower in this study than some of the more contaminated sites in the previous UK study [9].
As only a low number of roach were sampled below the STW in the Seine and the Béthune, it is impossible to draw any conclusion on the influence of the effluents on the intersex condition.

This work also showed that a number of fish were parasitised. This might contribute to impair both gonadal development and reproductive success of the fish. Particularly at Poses, on the River Seine, a number of criteria showed that fish health is severely impaired. This includes reduced GSI, high incidence of parasitism and abnormal cell division during oogenesis (as seen in gudgeon).

Finally, roach is not the only species that showed occurrence of ovotestis. Chubb and gudgeon developed similar abnormalities. Although the numbers of chubb caught were low, the differences in intersex incidence between roach and chubb suggest that this species may be less susceptible to endocrine disruption.

\section{Acknowledgements}

This study was made possible through support from the INTERREG II programme of the European Regional Development Fund, the Environment Agency (England, Southern Region), the Agence de l'Eau, the Région HauteNormandie and the DIREN. The authors are grateful to Dr S. Jobling, Brunel University, and Dr D. Caillez at the Monod Hospital (France) for advice on the histological analyses and interpretation. The authors would like to thank all the people who help in sampling and in sectioning.

\section{References}

1. Tyler, C.R.; Jobling, S.; Sumpter, J.P. Critical Rev. Toxicol. 1998, 28, 319-361.

2. Toppari, J.; Larsen, J.C.; Christiansen, P.; Giwercman, A.; Grandjean, P. et al. Environ. Health Perspect. 1996, 104, 741803.

3. Arukwe, A.; Goksøyr, A. Sarsia 1998, 83, 225-241.

4. Kime, D.E. Rev. Fish Biol. Fisheries 1995, 5, 52-96.

5. Gimeno, S; Gerritsen, A.; Bowmer, T.; Komen, H. Nature 1996, 384, 221-222. 
6. Allen, Y.; Scott, A.P.; Matthiessen, P.; Haworth, S.; Thain, J.E.; Feist, S. Environ. Toxicol. Chem. 1999, 18, 1791-1800.

7. Minier, C.; Levy, F; Rabel, D.; Bocquené, G.; Godefroy, D.; Burgeot, T.; Leboulenger, F. Mar. Environ. Res. 2000, 50, 69-73.

8. Wiklund, T.; Lounasheimo, L.; Lom, J.; Bylund, G. Dis. Aquat. Org. 1996, 23, 163-161.

9. Jobling, S.; Nolan, M.; Tyler, C.R.; Brighty, G.; Sumpter, J.P. Environ. Sci. Technol. 1998, 32, 2498-2506.

10. Lye, C.M.; Frid, L.J.; Gill, M.E.; McCormick, D. Mar. Poll. Bull. 1997, 34, 34-41.

11. Harries, J. E.; Janbakhsh, A.; Jobling, S.; Matthiessen, P.; Sumpter, J. P.; Tyler, C.R Environ. Toxicol. Chem. 1999, 18, 932-937.

12. Elsrud Shou, A.; Mona, E.; Wiborg, M.; Tollefsen, K.-E.; Stenersen, J.; Knudsen, F.R. Abstract, VII International Symposium on Fish Physiology, 3-6 April 1996, Oslo, Norway.
13. Larsson, D. G. J.; Adolfsson-Erici, M.; Parkkonen, J.; Pettersson, M.; Berg, A. H.; Olsson, P. E.; Förlin, L. Aquatic Toxicol. 1999, 45, 91-97.

14. Nichols, K. M.; Miles-Richardson, S. R.; Snyder, E. M.; Giesy, J. P. Environ. Toxicol. Chem. 1999, 18, 2001-2012.

15. Desbrow, C.; Routledge, E.J.; Brighty, G.C.; Sumpter, J.P.; Waldock, M. Environ. Sci. Technol. 1998, 32, 1549-1558.

16. Routledge, E.J.; Sheahan, D.; Desbrow, C.; Brighty, G.C.; Waldock, M.; Sumpter, J.P. Environ. Sci. Technol. 1998, 32, 1559-1565.

17. White, R.; Jobling, S.; Hoare, S.A.; Sumpter, J.P.; Parker, M.G. Endocrinology 1994, 135, 175-182.

18. S.E.M.A. H.N. Données hydrologiques, DIREN, Agence de l'Eau, 1995.

19. Iguchi, T.; Fukazawa Y.; Uesugi Y.; Takasugi, N. Biol. Reprod. 1990, 43, 478-484.

20. Arme, C. J. Helminth. 1997, 71, 83-84. 